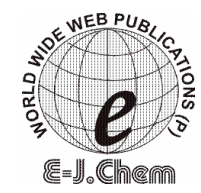

http://www.e-journals.net

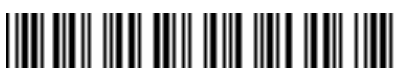

ISSN: 0973-4945; CODEN ECJHAO

E-Journal of Chemistry

Vol. 5, No. 1, pp. 100-106, January 2008

\title{
A Sensitive Spectrophotometric Determination of Ritodrine, Pentazocine, Isoxsuprine Hydrochlorides and Amoxicillin in Pure and Pharmaceutical Samples
}

\author{
H. D. REVANASIDDAPPA* and M. A. VEENA \\ Department of Chemistry, University of Mysore, \\ Manasagangothri, Mysore-570 006, India.
}

hdrevanasiddapp@yahoo.com

Received 30 May 2007; Accepted 17 July 2007

\begin{abstract}
A simple, accurate and highly sensitive spectrophotometric method for the determination of ritodrine hydrochloride (RTH), pentazocine hydrochloride ( $\mathrm{PZH}$ ), isoxsuprine hydrochloride (ISH) and amoxicillin (AMX) is described. The method is based on the oxidation of the studied drugs by a known excess of chloramine - T (CAT) in hydrochloric acid medium and subsequent determination of the unreacted oxidant by reacting it with iodide in the same acid medium liberates iodine, which subsequently react with starch to form a stable starch-iodine complex. The reacted oxidant corresponds to the drug content. The coloured complex exhibits a maximum absorption at $590 \mathrm{~nm}$. The apparent molar absorptivity values and Sandell's sensitivity values are in the range $6.96 \times 10^{4}-1.43 \times 10^{5} \mathrm{~L} \mathrm{~mol}^{-1} \mathrm{~cm}^{-1}$ and $2.45-4.30 \mathrm{ng} \mathrm{cm}^{-2}$, respectively. The method was successfully applied to the studied drugs in their dosage forms. The results are reproducible within $\pm 1 \%$ and compare favorably with those of official methods of British Pharmacopoeia and the United States Pharmacopoeia.
\end{abstract}

Keywords: Spectrophotometry, Iodine - starch reagent, Drug analysis.

\section{Introduction}

Ritodrine hydrochloride (RTH), chemically 1-(4-hydroxy phenyl)-2-[2-(4- hydroxy phenyl) ethyl amino] propanol, is a $\beta_{2^{-}}$adrenergic agonist used to arrest preterm delivery in pregnant woman ${ }^{1,2}$. Pentazocine hydrochloride (PZH), ( 2R*,6R*,11R*)-1,2,3,4,5,6-hexahydro-6,11-dimethyl-3-(3methyl-2-butenyl)-2,6-methano-3-benzazocin-8-ol, is an analgesic with antagonist action. Amoxicillin (AMX), 6-( $p$-hydroxy- $\alpha$-aminophenyl acetamido) penicillanic acid, is used as an antibacterial drug. Isoxsuprine hydrochloride (ISH), $p$-hydroxy- $N$-(1-methyl-2-phenoxyethyl) 
norephedrine hydrochloride, is an active peripheral and cerebral vasodilator and it has a direct relaxant effect on the smooth muscular tissue of the blood vessels and uterus. In view of the increased pharmaceutical applications of RTH, PZH, AMX and ISH, their assay and quality control are very important. Spectrophotometric methods have been reported in the literature for the determination of $\mathrm{RTH}^{3-5}, \mathrm{PZH}^{6-7}, \mathrm{AMX}^{5,8,9}$ and $\mathrm{ISH}^{3,10,11}$. For the determination of studied drugs, other methods include HPLC, ${ }^{12-14}$ titrimetric $^{15}$ and fluorimetric ${ }^{16,17}$ are also reported in the literature. Some of these methods required expensive reagents, less sensitive, poor selective, time consuming and tedious experimental procedures. To overcome these limitations in the existing method, there is still a need for a sensitive and cost-effective method for the determination of these drugs that can be adopted for the routine analysis of pharmaceutical samples. In the present investigation, a highly sensitive indirect spectrophotometric determination of cited drugs with chloramine-T-iodine and starch is described, and the proposed method has been employed to the determination of studied drugs in pure and in dosage forms. This new procedure is accurate, highly sensitive, rapid, simple and completely different from the existing methods.

\section{Experimental}

\section{Apparatus}

All absorbance measurements were made with an Elico - model SL-171 digital spectrophotometer with $1 \mathrm{~cm}$ matched cells.

\section{Reagents}

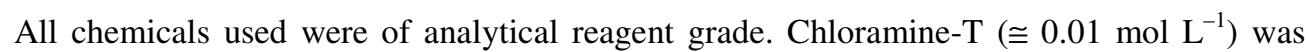
prepared by dissolving $0.28 \mathrm{~g}$ of CAT in $100 \mathrm{~mL}$ of distilled water and standardized iodometrically. This solution was then diluted subsequently to get $100 \mu \mathrm{g} \mathrm{mL}^{-1}$ solution. Starch $1 \%$ : It was prepared by dissolving $1.0 \mathrm{~g}$ of starch in $100 \mathrm{~mL}$ of hot distilled water. Solutions of potassium iodide $(0.5 \%)$ and hydrochloric acid $\left(2.0 \mathrm{~mol} \mathrm{~L}^{-1}\right)$ were used.

\section{Standard solution}

Aqueous solutions of pentazocine hydrochloride (PZH) (Sigma Laboratories Pvt. Ltd., Mumbai), amoxicillin (AMX) (Cadila Health Care Ltd. India), ritodrine hydrochloride (RTH) and isoxsuprine hydrochloride (ISH) (Duphar-Interfran Ltd., India) were prepared by dissolving the requisite amount of the samples in distilled water, working solutions prepared as required by dilution.

\section{Standard procedure}

Accurately measured volumes of drug solutions equivalent to 0.2-1.2, 0.2-1.6, 0.0 -1.5 and 0.5$2.5 \mu \mathrm{g} \mathrm{mL}^{-1}$ of final solution of $\mathrm{RTH}, \mathrm{PZH}, \mathrm{AMX}$ and ISH, respectively were transferred into a series of $10 \mathrm{~mL}$ standard flasks. Then a volume of $0.7 \mathrm{~mL}$ of $100 \mu \mathrm{g} \mathrm{mL}^{-1} \mathrm{CAT}$ was added to each flask followed by acidification by $1.0 \mathrm{~mL}$ of $2.0 \mathrm{~mol} \mathrm{~L}^{-1}$ hydrochloric acid. After $10 \mathrm{~min}$, $1.5 \mathrm{~mL}$ of $0.5 \% \mathrm{KI}$ was added to each flask. After $2.0 \mathrm{~min} 1.0 \mathrm{~mL}$ of $1 \%$ starch was added and the contents were diluted to the mark with distilled water and mixed well. The absorbance of the coloured complex was measured at $590 \mathrm{~nm}$ against distilled water after $5.0 \mathrm{~min}$. Blank was prepared similarly omitting the drug and its absorbance was measured against distilled water. The decrease in absorbance corresponding to consumed CAT and in turn, to drug concentration, obtained by subtracting the absorbance of a test solution from that of the blank solution. The calibration graph was drawn by plotting the difference in absorbance (absorbance values of test and blank solutions) of the complex against the amount of the drug. The amount of drug was determined from the concurrent calibration graph. 


\section{Procedure for pharmaceutical formulations}

In a $100 \mathrm{~mL}$ standard flask, an accurately weighed amount (from the mixed and powdered contents of 20 tablets or mixed contents of 10 capsules), equivalent to $50 \mathrm{mg}$ of the respective drug, was dissolved in $5.0 \mathrm{~mL}$ of methanol and completed to volume with distilled water and filtered. Appropriate aliquots of the drug solution were taken and the standard procedure was followed for analyzing the drug content.

To analyze the injection solution and syrup, the requisite amount was transferred to a $100 \mathrm{~mL}$ standard flask and dissolved in $5.0 \mathrm{~mL}$ of methanol and completed to volume with distilled water. The drug content in the diluted solution was determined as described above, and the results of the analysis are given in Table 1 .

Table 1. Results of assay of RTH, PZH, AMX and ISH in dosage forms

\begin{tabular}{|c|c|c|c|c|c|c|c|}
\hline \multirow[b]{2}{*}{$\begin{array}{l}\text { Drug and } \\
\text { Formulation }\end{array}$} & \multirow[b]{2}{*}{$\begin{array}{l}\text { Amount } \\
\text { taken } \\
\mu \mathrm{g} \mathrm{mL} L^{-1}\end{array}$} & \multicolumn{2}{|c|}{ Proposed Method $^{\mathrm{a}}$} & \multicolumn{2}{|c|}{ Reference Method $^{18,19}$} & \multirow[b]{2}{*}{ t-value ${ }^{b}$} & \multirow[b]{2}{*}{ F-value $^{c}$} \\
\hline & & $\begin{array}{l}\text { Amount } \\
\text { found } \\
\mu \mathrm{g} \mathrm{mL}^{-1}\end{array}$ & $\begin{array}{l}\% \operatorname{Rec} \\
\pm \mathrm{SD}\end{array}$ & $\% \mathrm{C} \mathrm{V}$ & $\begin{array}{l}\% \operatorname{Rec} \\
\pm \mathrm{SD}\end{array}$ & & \\
\hline RTH & 0.4 & 0.390 & $99.85 \pm 0.22$ & 0.56 & $100.06 \pm 0.34$ & 1.48 & 2.38 \\
\hline Yutopar tab & 0.8 & 0.805 & $100.68 \pm 0.37$ & 0.20 & $100.30 \pm 0.16$ & 2.26 & 5.35 \\
\hline $10 \mathrm{mg} / \mathrm{tab}$ & 1.2 & 1.206 & $100.54 \pm 0.44$ & 0.36 & $100.14 \pm 0.19$ & 2.40 & 5.48 \\
\hline Yutopar inj & 0.4 & 0.401 & $100.28 \pm 0.32$ & 0.79 & $99.70 \pm 0.55$ & 2.32 & 2.95 \\
\hline \multirow[t]{2}{*}{$50 \mathrm{mg} / 10 \mathrm{~mL}$} & 0.8 & 0.798 & $99.79 \pm 0.34$ & 0.42 & $100.09 \pm 0.58$ & 1.47 & 2.91 \\
\hline & 1.2 & 1.203 & $100.25 \pm 0.13$ & 0.10 & $100.17 \pm 0.26$ & 1.88 & 4.0 \\
\hline $\mathrm{PZH}$ & 0.4 & 0.399 & $99.94 \pm 0.32$ & 0.80 & $100.06 \pm 0.39$ & 0.66 & 1.48 \\
\hline Penzyl inj & 1.0 & 1.002 & $100.20 \pm 0.17$ & 0.16 & $100.15 \pm 0.12$ & 1.21 & 2.0 \\
\hline $30 \mathrm{mg} / \mathrm{mL}$ & 1.6 & 1.603 & $100.22 \pm 0.20$ & 0.12 & $100.06 \pm 0.12$ & 1.97 & 2.78 \\
\hline Fortwin inj & 0.4 & 0.399 & $99.85 \pm 0.35$ & 0.87 & $100.15 \pm 0.59$ & 1.16 & 2.84 \\
\hline \multirow[t]{2}{*}{$30 \mathrm{mg} / \mathrm{mL}$} & 1.0 & 1.004 & $100.43 \pm 0.64$ & 0.63 & $100.19 \pm 0.32$ & 1.68 & 4.00 \\
\hline & 1.6 & 1.608 & $100.54 \pm 0.66$ & 0.41 & $100.43 \pm 0.31$ & 0.90 & 4.50 \\
\hline AMX & 0.5 & 0.500 & $100.18 \pm 0.33$ & 0.66 & $99.81 \pm 0.55$ & 2.46 & 2.77 \\
\hline Amokid tab & 1.0 & 1.001 & $100.13 \pm 0.22$ & 0.21 & $100.01 \pm 0.43$ & 1.21 & 3.82 \\
\hline $250 \mathrm{mg} / \mathrm{tab}$ & 1.5 & 1.502 & $100.15 \pm 0.21$ & 0.13 & $99.99 \pm 0.48$ & 1.69 & 5.20 \\
\hline Hipen inj & 0.5 & 0.498 & $99.69 \pm 0.41$ & 0.82 & $100.03 \pm 0.59$ & 1.73 & 2.07 \\
\hline \multirow[t]{2}{*}{$250 \mathrm{mg} / \mathrm{mL}$} & 1.0 & 1.001 & $100.18 \pm 0.33$ & 0.32 & $99.81 \pm 0.61$ & 2.46 & 3.41 \\
\hline & 1.5 & 1.502 & $100.16 \pm 0.37$ & 0.24 & $99.88 \pm 0.78$ & 1.69 & 4.44 \\
\hline Amoxipen & 0.5 & 0.499 & $99.91 \pm 0.34$ & 0.68 & $99.60 \pm 0.54$ & 2.38 & 2.52 \\
\hline Syrup & 1.0 & 0.999 & $99.93 \pm 0.24$ & 0.24 & $99.80 \pm 0.42$ & 1.25 & 3.06 \\
\hline $125 \mathrm{mg} / 5 \mathrm{~mL}$ & 1.5 & 1.505 & $100.35 \pm 0.17$ & 0.11 & $100.17 \pm 0.35$ & 2.26 & 4.23 \\
\hline ISH & 1.0 & 0.995 & $99.56 \pm 0.44$ & 0.44 & $100.01 \pm 0.59$ & 1.73 & 1.64 \\
\hline Duvadilan tab & 1.5 & 1.500 & $100.06 \pm 0.67$ & 0.44 & $99.80 \pm 0.49$ & 0.86 & 1.86 \\
\hline $10 \mathrm{mg} / \mathrm{tab}$ & 2.0 & 2.001 & $100.09 \pm 0.65$ & 0.32 & $99.50 \pm 0.43$ & 1.96 & 2.28 \\
\hline Tidilan inj & 1.0 & 1.003 & $100.30 \pm 0.45$ & 0.45 & $100.31 \pm 0.52$ & 0.86 & 1.34 \\
\hline \multirow[t]{2}{*}{$5 \mathrm{mg} / \mathrm{mL}$} & 1.5 & 1.506 & $100.43 \pm 0.64$ & 0.31 & $100.19 \pm 0.47$ & 0.85 & 1.85 \\
\hline & 2.0 & 2.00 & $100.00 \pm 0.90$ & 0.45 & $99.73 \pm 0.56$ & 0.71 & 2.58 \\
\hline
\end{tabular}

a Average of five determinations, b Tabulated value 2.78 , c Tabulated value 6.39 


\section{Results and Discussion}

Preliminary experiment was performed to fix the linear range (Beer's law curve) for chloramine-T (CAT) in the optimum experimental conditions, with the use of iodine-starch reagent. Under experimental conditions, the concentration range of CAT was found to be $0-7.0 \mu \mathrm{g} \mathrm{mL}^{-1}$. In the present work, known but excessive CAT was utilized to oxidize the studied drugs in $2.0 \mathrm{~mol} \mathrm{~L}^{-1}$ hydrochloric acid medium and the unreacted CAT was determined by reacting it with iodine - starch reagent in the same acidic system. The coloured complex shows a maximum absorption at $590 \mathrm{~nm}$. This formed the basis for the determination of studied drugs in microgram quantities. The studied drugs, when added in increasing amounts to fixed amount of chloramine-T, drugs consume CAT and there is a concomitant decrease in the absorbance of the coloured complex on increasing the concentration of drugs (Figure 1).

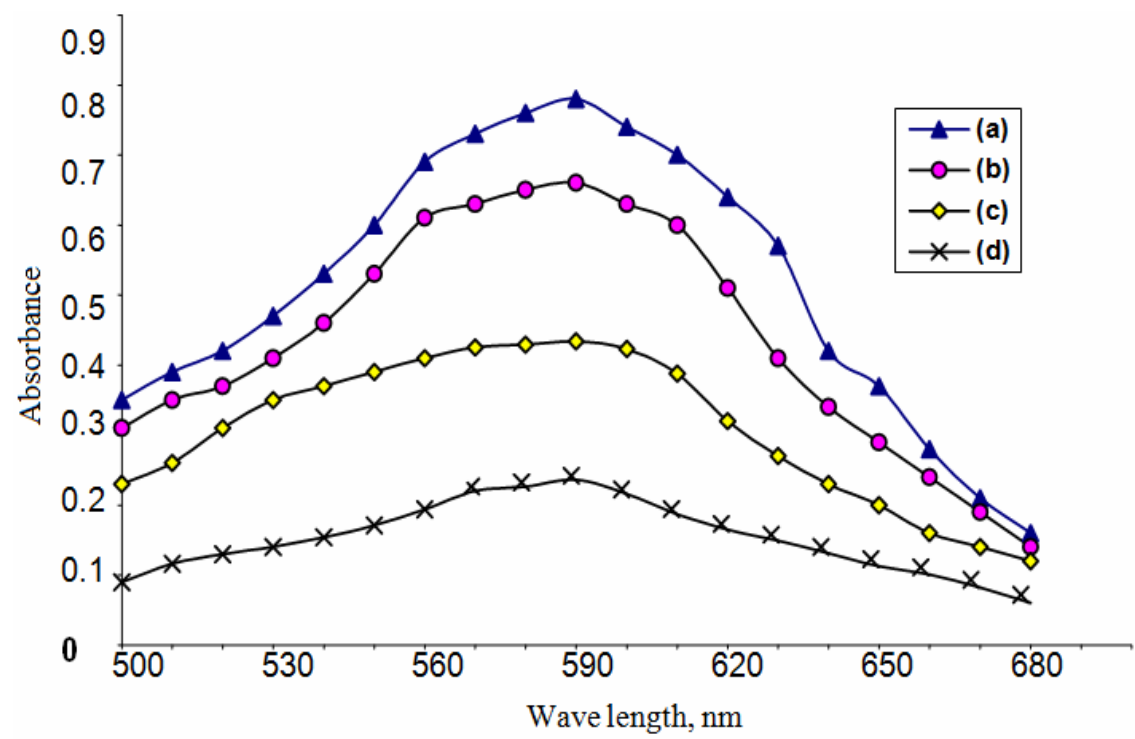

Figure 1. Absorption spectra of the CAT - iodine -starch complex with ISH (a) Blank (without ISH) (b) $0.5 \mu \mathrm{g} \mathrm{mL}^{-1}$ (c) $1.5 \mu \mathrm{g} \mathrm{mL} \mathrm{m}^{-1}$ (d) $2.5 \mu \mathrm{g} \mathrm{mL}^{-1}$ measured against water.

The general reaction scheme of the method for studied drugs with CAT is represented as follows:

Studied Drugs + CAT $\stackrel{\mathrm{H}^{+}}{\longrightarrow}$ Oxidized Drugs + Reduced CAT + Unreacted CAT
Unreacted CAT + KI $\stackrel{\mathrm{H}^{+}}{\longrightarrow}$ Liberated Iodine
Liberated Iodine + Starch $\underset{\mathrm{H}^{+}}{\longrightarrow}$ Starch-Iodine blue coloured complex

Effects of acid and reagents

Hydrochloric acid was the medium of choice for oxidation of the drugs by CAT as well as the latter's determination with iodine-starch reagent. A $1.0 \mathrm{~mL}$ of $2.0 \mathrm{~mol} \mathrm{~L} \mathrm{~L}^{-1}$ concentration of $\mathrm{HCl}$ was found optimum for the oxidation of the drugs within $10 \mathrm{~min}$, and hence the same concentration was employed for the determination of CAT with iodine-starch reagent. The volume of $1.5 \mathrm{~mL}$ of $0.5 \% \mathrm{KI}$ and $1.0 \mathrm{~mL}$ of $1.0 \%$ starch solution in a total volume of $10 \mathrm{~mL}$ of reaction mixture were found suitable for the analysis. 


\section{Reaction time and stability of colour}

The time taken for complete oxidation of the drugs is not critical. Any delay up to 45 min in the determination of unreacted CAT had no effect on the absorbance. The colour of the formed iodine - starch complex was stable for a period of more than $90 \mathrm{~min}$ for the studied drugs.

\section{Effect of excipients}

In pharmaceutical analysis, it is important to test the accuracy of the method, so recovery experiments were performed using a synthetic mixture of each drug (RTH, PZH, ISH and AMX) with several excipients such as talc, stearic acid, gum acacia, dextrose, sodium alginate etc. by the proposed method and recoveries obtained were in the range 99.8-101.2\%. The results suggested that the usual tablet diluents and excipients were found not to interfere with the analysis by the proposed method.

\section{Analytical data}

The Beer's law limit, molar absorptivity, Sandell's sensitivity, correlation coefficient, detection and quantitation limits obtained by least square treatment of the results are given in Table 2 .

Table 2. Optical characteristics and precision data

\begin{tabular}{lcccc}
\hline \multicolumn{1}{c}{ Parameter } & RTH & PZH & ISH & AMX \\
\hline Beer's law limit, $\mu \mathrm{g} \mathrm{mL}^{-1}$ & $0.2-1.2$ & $0.2-1.6$ & $0.5-2.5$ & $0.0-1.5$ \\
Molar absorptivity, $\mathrm{L} \mathrm{mol}^{-1} \mathrm{~cm}^{-2}$ & $1.32 \times 10^{5}$ & $8.08 \times 10^{4}$ & $6.96 \times 10^{4}$ & $1.43 \times 10^{5}$ \\
Sandell's sensitivity, $\mu \mathrm{g} \mathrm{cm}^{-2}$ & 0.0024 & 0.0035 & 0.0043 & 0.0029 \\
Correlation coefficient [r] & 0.999 & 0.999 & 0.999 & 0.999 \\
Regression equation [y*] & & & & \\
Slope [b] & 0.3665 & 0.2493 & 0.2126 & 0.3381 \\
Intercept [a] & 0.0220 & 0.0232 & 0.0216 & 0.0031 \\
Detection limit [DL], $\mu \mathrm{g} \mathrm{mL} \mathrm{mL}^{-1}$ & 0.0427 & 0.0504 & 0.1126 & 0.0354 \\
Quantitation limit [QL], $\mu \mathrm{g} \mathrm{mL}^{-1}$ & 0.1296 & 0.1529 & 0.3414 & 0.1183 \\
\hline
\end{tabular}

$* \mathrm{Y}=\mathrm{a}+\mathrm{bx}$. where $\mathrm{x}$ is the concentration in $\mu \mathrm{g} \mathrm{mL} \mathrm{L}^{-1}$.

\section{Applications}

The proposed method was applied to the quantitative determination of studied drugs in pharmaceutical formulations and the results (Table 1) compare favorably with the official methods of the United States Pharmacopoeia ${ }^{18}$ and British Pharmacopoeia. ${ }^{19}$ A statistical analysis of the results by $\mathrm{f}$ - and t-tests at $95 \%$ confidence level showed no significant difference in the accuracy between the proposed method and official methods (Table 1). To ascertain the ruggedness of the method, four replicate determinations at two different concentration levels of the drugs were carried out. The within-day RSD values were less than $1 \%$. The values of between-day RSD for different concentrations of drugs, obtained from four determinations carried out over a period of 4 days, are given in Table 3, and indicate that the proposed method has reasonable ruggedness. 
Table 3. Between-day precision of the determination of cited drugs by the proposed method

\begin{tabular}{cccc}
\hline Drug & Amount taken, $\mu \mathrm{g}$ & Amount found $^{\mathrm{a}}, \mu \mathrm{g}$ & RSD, $\%$ \\
\hline RTH & 4.0 & 3.96 & 0.39 \\
& 10.0 & 9.97 & 0.22 \\
PZH & 6.0 & 5.95 & 0.50 \\
& 12.0 & 11.99 & 0.35 \\
AMX & 5.0 & 4.90 & 1.40 \\
& 12.5 & 12.49 & 0.27 \\
ISH & 10.0 & 9.90 & 0.35 \\
& 20.0 & 20.01 & 0.25 \\
\hline
\end{tabular}

\section{Conclusions}

The method developed is simple, selective and offer the advantages of high sensitivity and a wide range of determination without the need for heating or extraction. The colour developed is stable for a sufficient interval of time and the method unaffected by slight variations in the experimental conditions such as acidity and other reagents. The proposed method was compared with other reported spectrophotometric methods and found to be superior (Table 4). The proposed method can serve as an alternative method for the determination of the studied drugs in pure and in dosage forms.

Table 4. Comparison with other reported methods

\begin{tabular}{|c|c|c|c|c|}
\hline Reagent & $\begin{array}{c}\text { Beer's law limit } \\
\mu \mathrm{g} \mathrm{mL}^{-1}\end{array}$ & 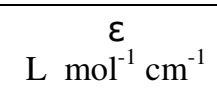 & Remarks & Reference \\
\hline N-bromosuccinimide & {$[\mathrm{AMX}] 1-20$} & $1.90 \times 10^{4}$ & Less sensitive & [8] \\
\hline Benzocaine & {$[\mathrm{AMX}] 2-16$} & $2.26 \times 10^{4}$ & $\begin{array}{l}\text { Less sensitive } \\
\text { and poor } \\
\text { selective }\end{array}$ & [9] \\
\hline 4-aminoantipyrine & $\begin{array}{l}{[\mathrm{RTH}] 2-22} \\
{[\mathrm{ISH}] 1-18}\end{array}$ & $\begin{array}{l}0.98 \times 10^{4} \\
1.20 \times 10^{4}\end{array}$ & Less sensitive & {$[3]$} \\
\hline $\begin{array}{l}\text { Sodium nitroprusside } \\
\text { and hydroxyl- } \\
\text { ammonium chloride }\end{array}$ & {$[\mathrm{PZH}] \quad 1-10$} & $1.28 \times 10^{4}$ & Less sensitive & [6] \\
\hline $\begin{array}{l}\text { 3-Methyl-1- } \\
\text { benzothiazolin-2-one } \\
\text { hydrazone[ MBTH] }\end{array}$ & 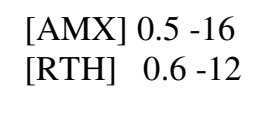 & $\begin{array}{l}2.35 \times 10^{4} \\
1.27 \times 10^{4}\end{array}$ & $\begin{array}{l}\text { Costly reagent } \\
\text { and } \\
\text { less sensitive }\end{array}$ & {$[5]$} \\
\hline $\begin{array}{l}\text { Chloramine-T-iodine- } \\
\text { starch }\end{array}$ & 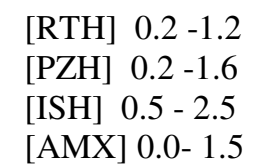 & $\begin{array}{l}1.32 \times 10^{4} \\
8.08 \times 10^{4} \\
6.96 \times 10^{4} \\
1.43 \times 10^{5}\end{array}$ & $\begin{array}{l}\text { Highly sensitive } \\
\text { and cost- } \\
\text { effective }\end{array}$ & $\begin{array}{l}\text { Present } \\
\text { method }\end{array}$ \\
\hline
\end{tabular}

\section{Acknowledgements}

One of the authors [M.A.V] is thankful to the University of Mysore, Mysore for providing the necessary facilities. 


\section{References}

1. Barden T P, Peter J B and Merkatz I R, Obstet. Gynecol.1980, 56, 1.

2. Reynolds E F, Martindale The Extra Pharmacopoeia. $31^{\text {st }}$ Ed., Royal Pharmaceutical Society, 1996, pp.1589.

3. Revanasiddappa H D and Manju B, J. AOAC Int'l. 2000, 83, 1440.

4. Revanasiddappa H D and Manju B, IL Farmaco. 2000, 56, 615.

5. Revanasiddappa H D, Manju B and Ramappa P G, Anal. Sci. 1999, 15, 661.

6. Sastry C S P and Rama Mohan Rao A, Indian.J.Pharm. Sci. 1986, 49, 95.

7. Shingbal D M, Sardesai and Girish D, Indian Drugs .1987, 24, 359.

8. Saleh. Gamal A, Analyst. 1996, 121, 641.

9. El-Ashry Saadia M, Fathalla Belal, Mohamed, El-Kerdawy M, Dalia and El-Wasseel R, Mikrochim. Acta, 2000, 135, 191.

10. Shankar D G, Sastry C S P, Reddy M N, and Shingh N R P, Indian Drugs. 1988, 25, 478.

11. Rajeshwar C V, Naidu D V, Naidu N V S and Naidu P R, Talanta. 1988, 35, 237.

12. Belal F, Al- Malaq H A, Al-Majecl A A and Gadkariem E A, J. Liq. Chromatogr. and Related Techno. 2000, 23, 3175.

13. Revanasiddappa H D and Manju B, J. Anal. Chem. 2003, 58, 775.

14. Volpe F, J Zintel J and Spiegel D, J. Pharm Sci. 1979, 68, 1264.

15. Safari A and Baezzat M R, Anal.Chim..Acta. 1998, 358,121.

16. Alarfaj and Newal A A, J. Pharm. Biomed. Anal. 2002, 28, 331.

17. Razak D A, J.Pharm. Biomed. Anal., 1998, 18, 359.

18. United States Pharmacopoeia Vol.24, National Formulary, U S Pharmacopoeial Convention, Rockville, M D, 2000, 1493.

19. British Pharmacopoeia Vol.1, Her Majesty Stationery Office, London, 2001, 2 - 6466, 22 - 52-53, 30 - 21-22. 


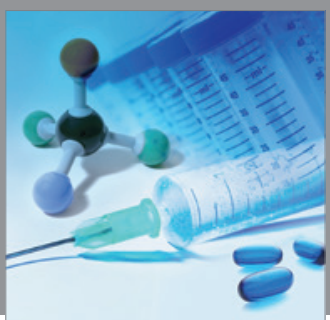

International Journal of

Medicinal Chemistry

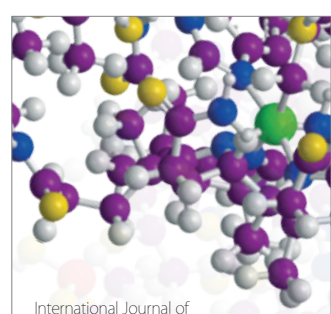

Carbohydrate Chemistry

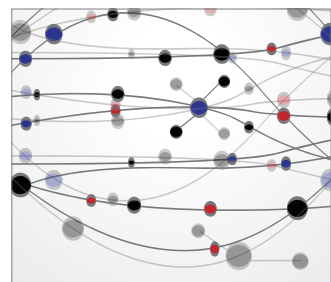

The Scientific World Journal
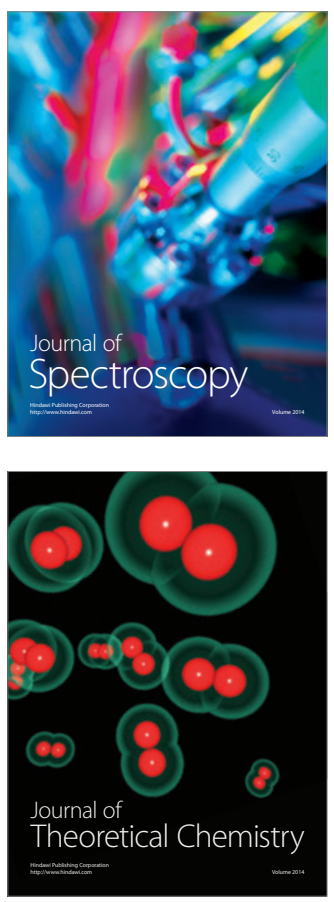
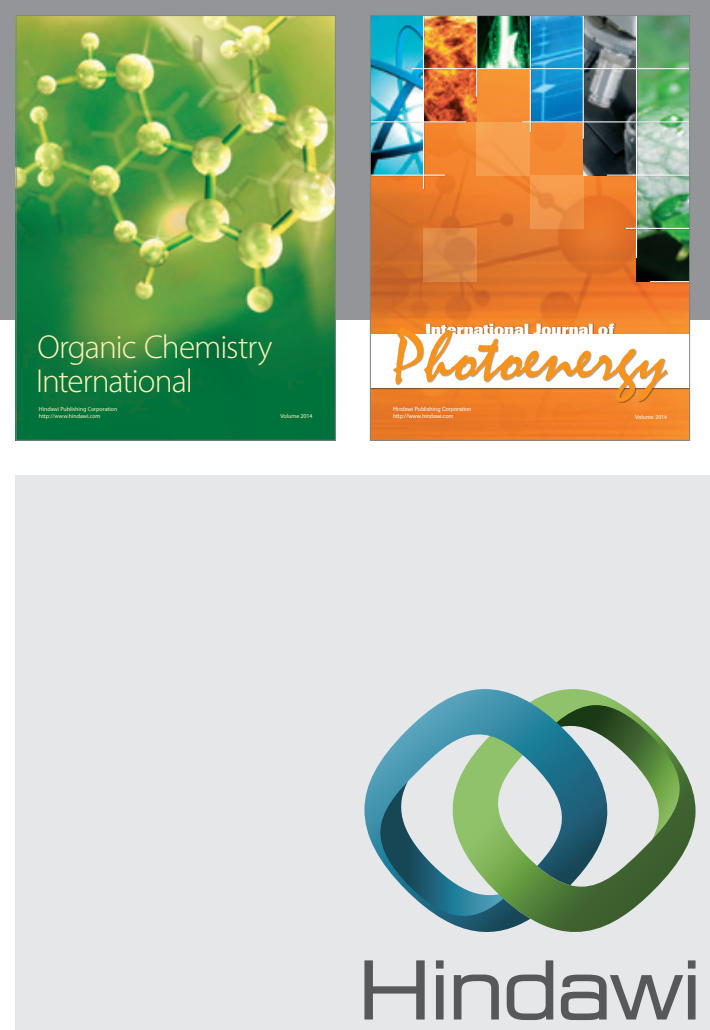

Submit your manuscripts at

http://www.hindawi.com
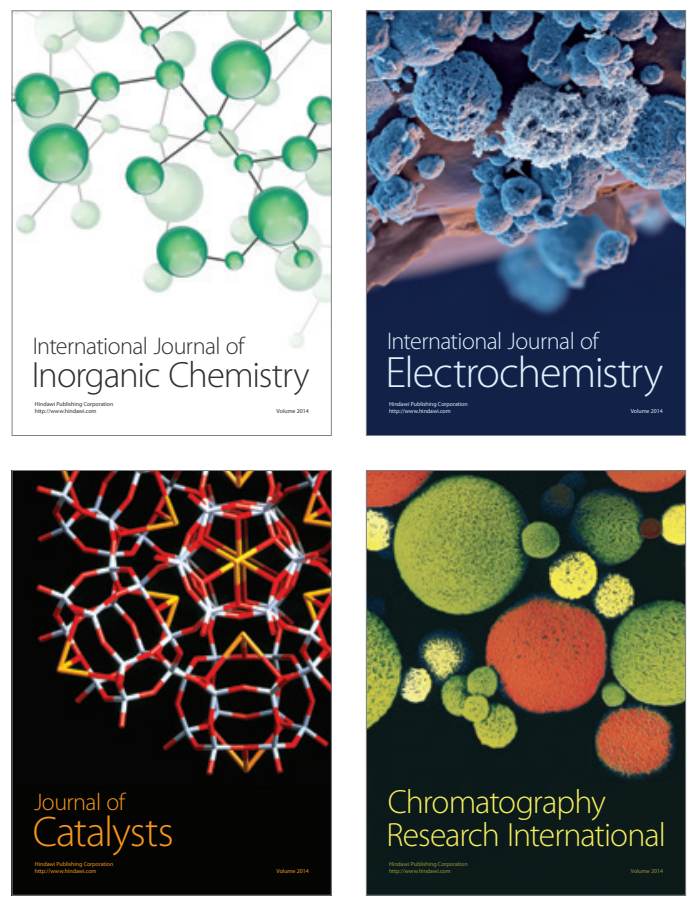
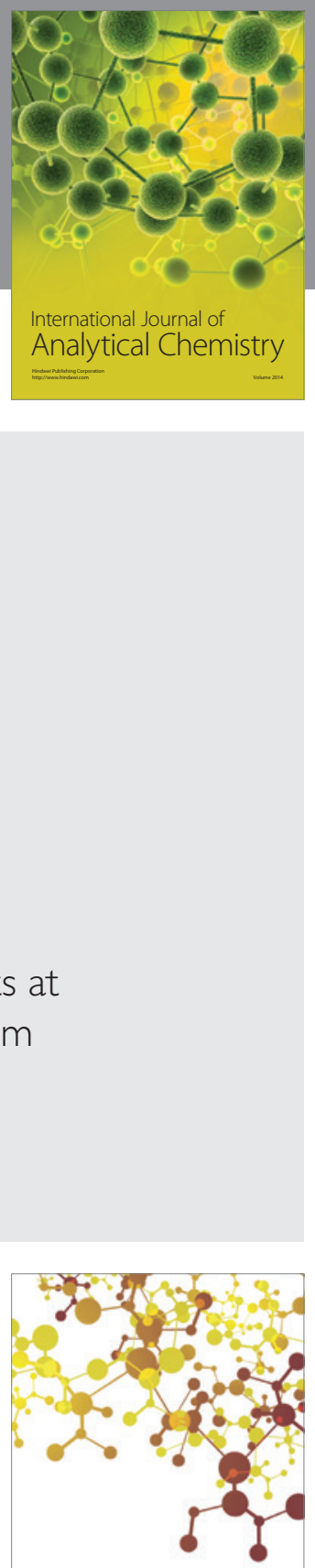

Journal of

Applied Chemistry
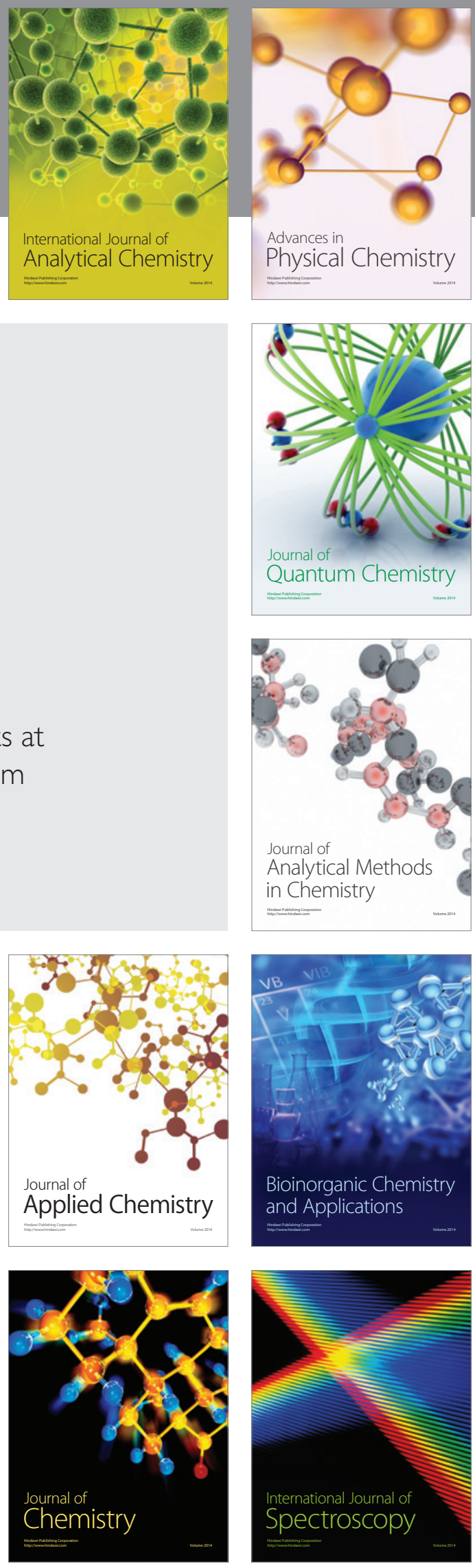